\title{
A Rare Case of Multifocal Intracranial Gangliogliomas: Mimicking Tuberculomas
}

\author{
Akshay Vijay Kulkarni ${ }^{1, ~ *, ~ G y a n i ~ J a i l ~ S i n g h ~ B i r u a ~}{ }^{1,}$, , Dhaval Gohil ${ }^{1}$, Manish Beniwal ${ }^{1}$, \\ Dwarakanath Srinivas ${ }^{1}$, Shilpa Rao ${ }^{2}$ \\ ${ }^{1}$ Department of Neurosurgery, National Institute of Mental Health and Neurosciences, Bengaluru, India \\ ${ }^{2}$ Department of Neuropathology, National Institute of Mental Health and Neurosciences, Bengaluru, India \\ Email address: \\ akshayvkulkarni@gmail.com (A. V. Kulkarni), akshaynimhans@gmail.com (A. V. Kulkarni), gya3944@nimhans.ac.in (G. J. S. Birua) \\ ${ }^{*}$ Corresponding author
}

\section{To cite this article:}

Akshay Vijay Kulkarni, Gyani Jail Singh Birua, Dhaval Gohil, Manish Beniwal, Dwarakanath Srinivas, Shilpa Rao. A Rare Case of Multifocal Intracranial Gangliogliomas: Mimicking Tuberculomas. Clinical Neurology and Neuroscience. Vol. 5, No. 3, 2021 , pp. 50-54. doi: $10.11648 /$ j.cnn.20210503.13

Received: June 24, 2021; Accepted: July 16, 2021; Published: July 23, 2021

\begin{abstract}
Gangliogliomas (GGs) are rare tumors of the central nervous system occurring in the young population (8.5-25 years). GGs are one of the most common cause of epilepsy associated with CNS tumors and significant proportion of them is refractory to antiepileptic medications. Multifocal gangliogliomas are very rare and only few handful cases are reported. A rare case of multiple spinal ganglioglioma has also been reported in the literature. We present a case of an adolescent girl who presented with multiple episodes of seizures. She was initially evaluated and diagnosed with multiple tuberculomas. She was managed with antiepileptics and antitubercular medications. Her seizure frequency had decreased; but despite prolonged and complete course of anti-tubercular treatment, the lesions were not subsiding in size. Antitubercular medications were restarted and subsequent scan showed progression in the size of the lesions; and hence biopsy was done from the largest lesion. Histopathology was suggestive of GG. Ganglioglioma can be multifocal and can mimic other lesions like tuberculosis, radiologically. Surgical excision of the lesion provides the best treatment option. It is still under consideration whether to remove all of the lesions or only ones with considerable size. She had another episode of seizure and is now planned for surgical excision of the other lesion.
\end{abstract}

Keywords: Multifocal Ganglioglioma, Intracranial Ganglioglioma, Tuberculoma

\section{Introduction}

Gangliogliomas are primary intra-axial solitary tumors of the central nervous system (CNS), with male preponderance occurring within first three decades of life. GGs account for $1-5 \%$ of all intracranial lesions in the pediatric age group and a common differential diagnosis in adolescent refractory epilepsy with lesion [1]. Multifocal GGs are very rare lesions To the best of our knowledge, six cases of intracranial and one case of multiple spinal gangliogliomas have been reported in the literature.

\section{Case Report}

A 15 years old girl presented with multiple episodes of seizure. MRI brain revealed multiple lesions- one in the right frontal operculum of about $2.5 \mathrm{~cm}$ dimension, second lesion in the right frontal convexity, and a third smaller lesion in the right inferior parietal region. All the lesions appeared surfacing/Dural-based and extending into cisternal spaces. The frontal lesion was variegated and spreading in the depth of Sylvian fissure up to MCA trunk bifurcation. Lesions were hypointense on T1, hyperintense on $\mathrm{T} 2$, and enhancing contrast (Figure $1 \mathrm{~A}$ to $\mathrm{E}$ ). A diagnosis of tuberculous/granulomatous inflammation was considered. Further evaluation with CT chest revealed pulmonary lesions suggestive of healed pulmonary tuberculosis. Hence, based on clinical and radiological 
findings initially treating physician made a diagnosis of multiple tuberculomas of CNS. She was started on Antitubercular treatment (ATT) and Antiepileptics were continued, and there were no further seizures. The followup MRI After 12 months of ATT showed an increase in the size of frontal and parietal lesions. There was diffusion restriction, and high choline peaks and some areas of high NAA peaks on MRS (Figure $1 \mathrm{H} \& \mathrm{I}$ ). In view of the progression of the disease, ATT was re-started by the treating neurologist. A repeat MRI performed 6 and 9 months later showed a further increase in the size of the lesions (Figure 1F \& G). At this stage, the patient was referred to us for tissue diagnosis. The right parietal lesion was large and surfacing, and hence, she underwent parietal craniotomy and resection of the lesion. Intraoperatively, the lesion was intra-axial, not adhered to the dura. There was no definitive plane between the lesion and the brain parenchyma, and safe subtotal resection was done. Histopathological section showed features of a glioneuronal tumor predominantly composed of lobules of clear oligodendroglia-like cells with interspersed branching fibrovascular septa. Larger appearing ganglion cells were seen interspersed within the stroma. Mitotic activity was inconspicuous. Many eosinophilic granular bodies were also noted. Glial fibrillary acidic protein highlighted the glial cells, and synaptophysin was positive in the ganglion cells. BRAFV600E immunohistochemistry was positive. (Figure 2).

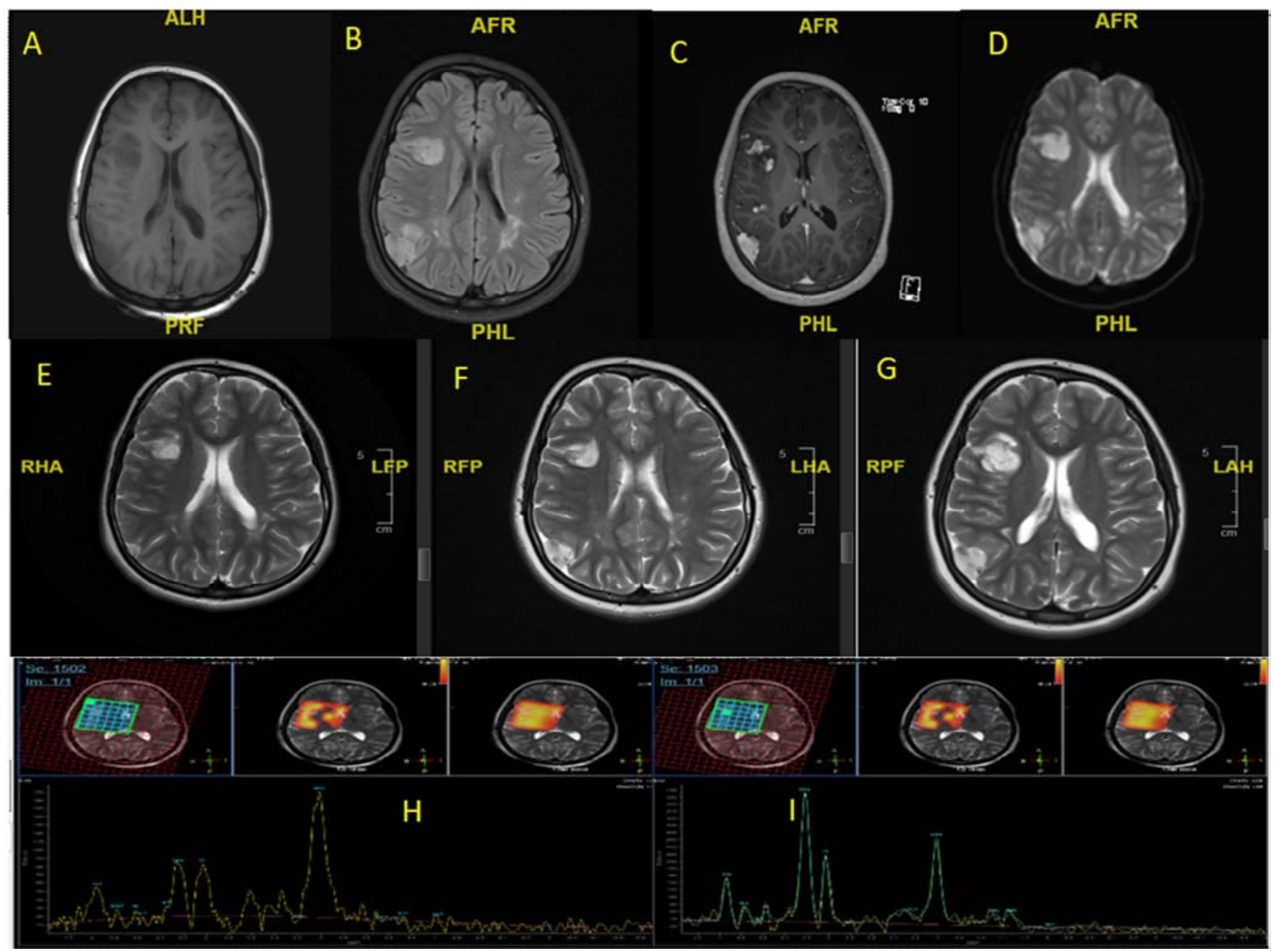

Figure 1. Pre-Operative MRI sequences

$\mathrm{A}=\mathrm{T} 1, \mathrm{~B}=$ Flair, $\mathrm{C}=$ Contrast, $\mathrm{D}=$ Diffusion weighted;

T2 images at serial interval: $E=$ Sept 2017, $F=$ Oct 2019, G=Feb 2020;

MRS H=Iso to hyper border of lesion- NAA $>$ Choline/Creat,

$\mathrm{I}=\mathrm{T} 2$ hyper region of the lesion- Choline increased $>$ NAA $>$ Creat

The patient was seizure free for 9 months after surgery and had one episode of breakthrough seizure. She did not have subsequent seizure at 18 months follow up. Patient and parents were offered the surgical option for frontal lesion but they have chosen not to undergo surgery at present. 

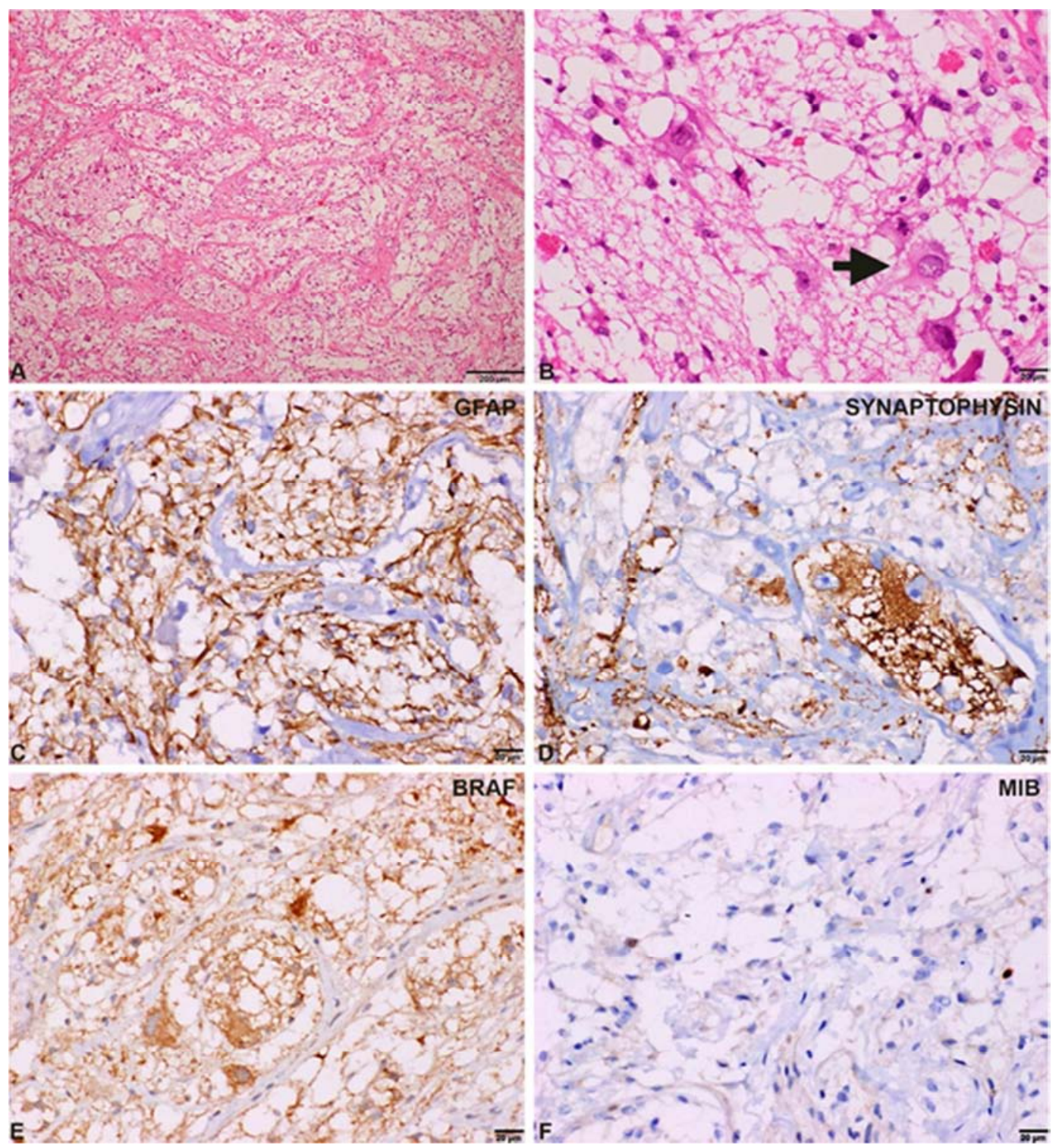

Figure 2. Histopathological slides.

$\mathrm{A}=\mathrm{H} \& \mathrm{E}$ Stain Low magnification, $\mathrm{B}=\mathrm{H} \& \mathrm{E}$ stain High magnification

$\mathrm{C}=\mathrm{GFAP}, \mathrm{D}=$ Synaptophysin, $\mathrm{E}=\mathrm{BRAF}, \mathrm{G}=\mathrm{MIB}$

\section{Discussion}

Gangliogliomas are benign lesions of young adults between 8.5-25 years of age [2]. They constitute less than $1 \%$ of the CNS lesions but constitute $7.6 \%$ of the pediatric lesions [3]. GGs usually present with seizures in $90 \%$ of cases, and a significant proportion of them are pharmacoresistant [3-5]. 40-84\% of lesions are located in the temporal lobe, but they can occur in almost any region of CNS [3]. Amongst the tumour-related temporal lobe epilepsy, GG constitutes $40 \%$ of the lesions [6]. $80 \%$ of gangliogliomas are WHO grade $1,10-15 \%$ are grade 2 , and $5-10 \%$ are anaplastic WHO grade 3 [7]. Asymptomatic and small lesions can be followed up. Surgical excision is the treatment of choice for symptomatic lesions.

These lesions usually have a good prognosis with more than $92 \%$ survival at five years and $85 \%$ at ten years [1]. Multiple gangliogliomas are very rare. Apart from the seven reports mentioned here, few disseminated GGs have been reported, but these were probably single lesions with CSF dissemination and seeding [9-11]. When they present as multifocal lesions, the GGs probably have a similar course, but the paucity of cases limits any conclusive evidence. The literature search indicates six cases of intracranial and one case of spinal multiple lesion $[3,8,12-16]$. Usually, GGs have a cystic component. Four out of the above six cases, including spinal, had only solid components. Amongst all these multiple GGs, operable lesions were resected [3, 8, 16], rest were appropriately biopsied (Table 1 ). In most cases who underwent biopsy, there was little / no preoperative suspicion of the lesion being GG. The presentation of the lesions varied as per the location and size. It included blurring of vision/ 
focal neuro deficit / non-specific headache / vomiting. Only one case which had two distinct lesions in the temporal lobe presented with seizures. This case was relieved of the seizures. Most of the other cases were relieved of the focal/ compressive symptoms caused by a lesion after resection [3, $8,12,16]$. With this limited number of cases, it is difficult to reach a consensus regarding the best treatment options. We think that lesions causing mass effect should be operated if not all of the lesions. Lesions with seizures present a dilemma for surgery- whether to be operated on with or without further seizure localization. Adjuvant therapy in the form of radiotherapy is advised in subtotal resection to increase better local control [5]. There is no definitive conclusion or consensus about chemotherapy for the GGs. For Grade I/II GGs there is no role for chemotherapy. Chemotherapy has a role in cases with the second recurrence despite surgery and adjuvant radiotherapy for first recurrence [17-18].

Table 1. Prior Case reports.

\begin{tabular}{|c|c|c|c|c|c|c|}
\hline \# & Author & Site & Location of the lesions & $\begin{array}{l}\text { Solid / } \\
\text { Cystic }\end{array}$ & Presentation & Surgery \\
\hline 1 & Paduch, 1999 & Cranial 33y /M & $\begin{array}{l}\text { Right Superior temporal } \\
\text { Gyrus }\end{array}$ & Solid & $\begin{array}{l}\text { Tonic clonic seizure, Preop } \\
\text { consideration - cavernomas, } \\
\text { Planned resection }\end{array}$ & $\begin{array}{l}\text { Resection of both lesions. Patient } \\
\text { was symptom free. }\end{array}$ \\
\hline 2 & Bradely 2003 & Cranial 8y /M & Bilateral Temporal, parietal & Solid & Bilateral temporal thickening. & $\begin{array}{l}\text { Left temporal biopsy followed by } \\
\text { bilateral Extracranial resection. }\end{array}$ \\
\hline 3 & Vajramani 2006 & Cranial 18y/M & $\begin{array}{l}\text { optic chiasm, left optic tract, } \\
\text { right lateral geniculate body, } \\
\text { and right optic radiation in } \\
\text { the temporal lobe }\end{array}$ & Cystic & $\begin{array}{l}\text { Visual Disturbance, Left Upper } \\
\text { limb sensory disturbance, non } \\
\text { specific headache, Planned biopsy } \\
\text { as optic pathway lesion was } \\
\text { considered }\end{array}$ & $\begin{array}{l}\text { Biopsy, Chemotherapy } 8 \text {, months } \\
\text { follow up. }\end{array}$ \\
\hline 4 & Lakhdar 2008 & Cranial 26y /F & $\begin{array}{l}\text { temporal lobe, the } \\
\text { diencephalomesencephalon } \\
\text { and the optical pathways }\end{array}$ & Cystic & $\begin{array}{l}\text { progressive tetraparesis, raised } \\
\text { intracranial pressure and visual } \\
\text { loss }\end{array}$ & Biopsy of right temporal lesion \\
\hline 5 & Ma 2015 & Cranial 20y /M & $\begin{array}{l}\text { Right Frontal, temporal, } \\
\text { occipital }\end{array}$ & Cystic & $\begin{array}{l}\text { Headache, nausea-vomiting, } \\
\text { fatigue, Planned Temporal and } \\
\text { occipital lesion. }\end{array}$ & $\begin{array}{l}\text { Resection. Frontal lesion } \\
\text { resection planned. }\end{array}$ \\
\hline 7 & $\begin{array}{l}\text { Wang-bradely } \\
2016\end{array}$ & $\begin{array}{l}\text { Spinal - Conus } \\
\text { Medullaris } 35 \mathrm{y} / \\
\text { F }\end{array}$ & $\begin{array}{l}\text { Conus medullaris and Filum } \\
\text { Terminalw }\end{array}$ & Solid & $\begin{array}{l}\text { Back pain, hip discomfort, tingling } \\
\text { in the legs, occasional fall. Plan } \\
\text { Biopsy/Resection }\end{array}$ & $\begin{array}{l}\text { Resection of Filum lesion, } \\
\text { Biopsy of the conus lesion. }\end{array}$ \\
\hline 6 & Mansour 2019 & Cranial 60y / F & $\begin{array}{l}\text { Multiple lesion both } \\
\text { hemispheres }\end{array}$ & Solid & Blurring of vision & Biopsy of occipital lesion \\
\hline 7 & Present Case & Cranial $15 y / F$ & $\begin{array}{l}\text { Frontal operculum, frontal } \\
\text { convexity, parietal }\end{array}$ & Solid & Seizures & $\begin{array}{l}\text { Subtotal resection of parietal } \\
\text { lesion }\end{array}$ \\
\hline
\end{tabular}

\section{Conclusion}

We, with this, present one of the handfuls of multifocal ganglioglioma cases to add to the limited database for enhancing future study or treatment guidelines. We consider that for optimum treatment and outcome for patients, each GG lesion must be treated based on symptoms, mass effect, and asses for resectability. Complete surgical excision is the treatment of choice. Radiotherapy is an effective adjuvant in subtotal resection and recurrent cases.

\section{Statement of Ethics}

Written informed consent was obtained from the patient for publication of this case report and any accompanying images. As this is a case report and patient identity is not revealed; Ethical approval was not required for this study in accordance with national guidelines.

\section{Conflict of Interest Statement}

All the authors do not have any possible conflicts of interest.

\section{References}

[1] Dudley RW, Torok MR, Hoffman L, Levy JM, Handler MH, Liu AK, et al. Response to Journal Club: Pediatric Low-Grade Ganglioglioma: Epidemiology, Treatments, and Outcome Analysis of 348 Children From the Surveillance, Epidemiology, and End Results Database. Neurosurgery. 2016; 79 (2): 309 . Epub 2016/07/20. doi: 10.1227/NEU.0000000000001275. PubMed PMID: 27428632.

[2] Louis DN, Perry A, Reifenberger G, von Deimling A, Figarella-Branger D, Cavenee WK, et al. The 2016 World Health Organization Classification of Tumors of the Central Nervous System: a summary. Acta Neuropathol. 2016; 131 (6) 803-20. Epub 2016/05/10. doi: 10.1007/s00401-016-1545-1. PubMed PMID: 27157931.

[3] Paduch T, Baborie A, Krauss JK. Bifocal temporal ganglioglioma. Neurosurg Rev. 1999; 22 (2-3): 112-6. Epub 1999/11/05. doi: 10.1007/s101430050042. PubMed PMID: 10547009 .

[4] Silver JM, Rawlings CE, 3rd, Rossitch E, Jr., Zeidman SM, Friedman AH. Ganglioglioma: a clinical study with long-term follow-up. Surg Neurol. 1991; 35 (4): 261-6. Epub 1991/04/01. doi: 10.1016/0090-3019(91)90002-q. PubMed PMID: 2008640. 
[5] Rades D, Zwick L, Leppert J, Bonsanto MM, Tronnier V, Dunst $\mathrm{J}$, et al. The role of postoperative radiotherapy for the treatment of gangliogliomas. Cancer. 2010; 116 (2): 432-42. Epub 2009/11/13. doi: 10.1002/cncr.24716. PubMed PMID: 19908258.

[6] Gregory N. Fuller TR, david M. Wildrick. Brain Tumors: An Overview of Current Histopathologic and Genetic Classification. In: Winn HR, editor. Youmans \& Winn Neurological Surgery, $7^{\text {th }}$ Edition. $7^{\text {th }}$ ed2017. p. 768-70.

[7] Wolf HK, Muller MB, Spanle M, Zentner J, Schramm J, Wiestler OD. Ganglioglioma: a detailed histopathological and immunohistochemical analysis of 61 cases. Acta Neuropathol. 1994; 88 (2): 166-73. Epub 1994/01/01. doi: 10.1007/BF00294510. PubMed PMID: 7985497.

[8] Ma SP, Tsui A, Kaye AH. Multicentric hemispheric ganglioglioma in a 20-year-old adult. J Clin Neurosci. 2015; 22 (2): 418-20. Epub 2014/10/12. doi: 10.1016/j.jocn.2014.08.003. PubMed PMID: 25304433.

[9] de Abreu PP, Muniz BC, Ventura N, Gasparetto E, Marchiori E. Intraventricular ganglioglioma with dissemination of cerebrospinal fluid. Radiol Bras. 2018; 51 (4): 272-73. Epub 2018/09/12. doi: 10.1590/0100-3984.2016.0222. PubMed PMID: 30202135; PubMed Central PMCID: PMCPMC6124589.

[10] Yamamoto T, Komori T, Shibata N, Toyoda C, Kobayashi M. Multifocal neurocytoma/gangliocytoma with extensive leptomeningeal dissemination in the brain and spinal cord. Am J Surg Pathol. 1996; 20 (3): 363-70. Epub 1996/03/01. doi: 10.1097/00000478-199603000-00014. PubMed PMID: 8772791 .

[11] Lummus SC, Aisner DL, Sams SB, Foreman NK, Lillehei KO, Kleinschmidt-DeMasters BK. Massive dissemination from spinal cord gangliogliomas negative for BRAF V600E: report of two rare adult cases. Am J Clin Pathol. 2014; 142 (2): 25460. Epub 2014/07/13. doi: 10.1309/AJCPIBSV67UVJRQV. PubMed PMID: 25015869; PubMed Central PMCID: PMCPMC4616006.
[12] Bradley JP, Kure K, Kawamoto HK. Bitemporal ganglioglioma: surgical management of an unusual intracranial and extracranial tumor. Plast Reconstr Surg. 2003; 111 (7): 2328-32. Epub 2003/06/10. doi: 10.1097/01.PRS.0000060798.99796.05. PubMed PMID: 12794476.

[13] F. Lakhdar M. Laghmari R. Gana R. Maaqili F. Bellakhdar. Gangliogliomes multiples intracrâniens: À propos d'un casMultiple intracranial ganglioglioma: Case report. Neurochirurgie. $2008 ; \quad 54 \quad$ (2): $97-100$. doi: https://doi.org/10.1016/j.neuchi.2007.12.006.

[14] Mansour S, Luther E, Eichberg DG, Shah A, Echeverry N, Humayun Gultekin S, et al. Multifocal Intracranial Ganglioglioma in a Sexagenarian: Case Report and Review of the Current Literature. World Neurosurg. 2020; 138: 498-503. Epub 2019/12/27. doi: 10.1016/j.wneu.2019.12.084. PubMed PMID: 31877395.

[15] Vajramani GV, Dambatta S, Walker M, Grundy PL. Multiple gangliogliomas of the optic pathway. Br J Neurosurg. 2006; 20 (6): 428-30. Epub 2007/04/19. doi: 10.1080/02688690601101382. PubMed PMID: 17439099.

[16] Wang JL HC, Otero J, Puduvalli VK, Elder JB. Genetic characterization of a multifocal ganglioglioma originating within the spinal cord. World neurosurgery. 2016; 96: 608-e1.

[17] Song JY, Kim JH, Cho YH, Kim CJ, Lee EJ. Treatment and outcomes for gangliogliomas: a single-center review of 16 patients. Brain Tumor Res Treat. 2014; 2 (2): 49-55. Epub 2014/11/20. doi: 10.14791/btrt.2014.2.2.49. PubMed PMID: 25408925; PubMed Central PMCID: PMCPMC4231627.

[18] Majores M, von Lehe M, Fassunke J, Schramm J, Becker AJ, Simon M. Tumor recurrence and malignant progression of gangliogliomas. Cancer. 2008; 113 (12): 3355-63. Epub 2008/11/07. doi: 10.1002/cncr.23965. PubMed PMID: 18988291. 